\title{
Oenological and Quality Characteristic on Young White Wines (Sauvignon Blanc): Effects of High Hydrostatic Pressure Processing
}

\author{
Vilbett Briones-Labarca, ${ }^{1,2}$ Mario Perez-Wom, ${ }^{1,2}$ \\ George Habib, ${ }^{1}$ Claudia Giovagnoli-Vicuña, ${ }^{1}$ Raúl Cañas-Sarazua, ${ }^{1}$ \\ Gipsy Tabilo-Munizaga, ${ }^{2,3}$ and Fernando N. Salazar ${ }^{4}$ \\ ${ }^{1}$ Food Engineering Department, Universidad de La Serena, Av. Raúl Bitrán Nachary 1305, Box 599, La Serena, Chile \\ ${ }^{2}$ Center for Advanced Studies in Arid Zones, CEAZA, Av. Raúl Bitrán Nachary 1305, Box 599, La Serena, Chile \\ ${ }^{3}$ Food Engineering Department, Universidad del Bío-Bío, Av. Andrés Bello s/n, Chillán, Chile \\ ${ }^{4}$ School of Food Engineering, Pontificia Universidad Católica de Valparaíso, Av. Waddington 716, Valparaíso, Chile
}

Correspondence should be addressed to Vilbett Briones-Labarca; vbriones@userena.cl

Received 1 July 2016; Revised 6 October 2016; Accepted 18 October 2016; Published 11 January 2017

Academic Editor: Susana Fiszman

Copyright (c) 2017 Vilbett Briones-Labarca et al. This is an open access article distributed under the Creative Commons Attribution License, which permits unrestricted use, distribution, and reproduction in any medium, provided the original work is properly cited.

\begin{abstract}
High hydrostatic pressure (HHP) has shown to have an effect of enhancing some properties without detrimental effects on important quality characteristics, such as colour, $\mathrm{pH}$, and turbidity. This suggests that this technique can be used as an alternative to the existing methods used in wine industry processing. The aim of this study was to investigate the effects of HHP on aroma compounds and also sensory and quality properties of young white wine. HHP treatment did not influence physicochemical parameters, total phenols, and flavonoid contents of white wine; however, the results from analysis of wine indicate that there was a great variation in the concentration of free and total sulphur dioxide $\left(\mathrm{SO}_{2}\right)$ values and antioxidant capacity of white wine after HHP application. The sensory attributes, such as taste, odour, and overall quality, were not affected by HHP processing at $300 \mathrm{MPa}$. The chromatic characteristics changed slightly after applying HHP, but these changes could not be visually perceived because they were less than $5 \%$. The use of this technique has the potential to decrease the amount of $\mathrm{SO}_{2}$ added to raw grapes thus maintaining the same properties found in untreated wine. This study provided valuable insights into the biochemical and sensory composition of commercial white wine and how this might change during HHP processing.
\end{abstract}

\section{Introduction}

Wine is an alcoholic beverage made up of water ( $80 \%$ to $85 \%)$, alcohols (mostly ethanol, $9 \%$ to $15 \%$ ), and a variety of minor constituents $(\sim 3 \%)$ [1]. Such minor constituents include organic acids, sugars, phenols, nitrogenous compounds, enzymes, vitamins, lipids, inorganic anions and cations, and a large number of volatile compounds. Of these, organic acids and phenols play a critical role by directly affecting product quality. Wine flavour is a complex mixture of taste and aroma attributes; the first is made up of a subtle balance of sweet (sugars), sour (organic acids), and bitter/astringent (polyphenols) taste attributes; the second is made up of a large number of volatile compounds belonging to alcohol classes (lower and higher), organic esters, volatile organic acids, aldehydes, lactones, phenols, sulphur-containing compounds, methoxypyrazines, norisoprenoids, ketones, and terpenes all of which contribute to wine aroma [2].

The quality and safety of food products are some of the most important factors influencing consumer choices in modern times [3]. Today's consumers demand high-quality foods to be additive-free, fresh in flavour, microbiologically safe, and with an extended shelf life [4]. Since 1985, the US Food and Drug Administration (FDA) has required package labelling for most foods and beverages when sulphites are used as an additive. Due to its antiseptic and antioxidant properties, sulphur dioxide $\left(\mathrm{SO}_{2}\right)$ is one of the most versatile 
and efficient additives used in winemaking. All the wines sold in the United States via interstate commerce include a warning statement if they contain more than $10 \mathrm{ppm}$ sulphites. Although the population of sulphite-sensitive consumers is relatively small, the perception that sulphites can cause negative health effects is still common.

During the last decade, high hydrostatic pressure (HHP) technology has been used in food processing because it offers several advantages compared to traditional food conservation and hygiene methods [4]. Some important advantages of this technology in the food industry include (a) microorganism and enzyme inactivation, (b) biopolymer modification, (c) quality retention, such as colour and flavour, and (d) changes in product functionality [5]. A whole range of food products currently being treated by HHP, such as fruit juices, seafood, and meat products, can be found on storing shelves around the world [6-8].

HHP use in wine is a relatively new application. It can usually be used to either inactivate undesirable microorganisms in wine or change its physicochemical and sensory properties. Tao et al. [9] and Corrales et al. [10] found that the biochemical stabilisation of wine was affected by HHP when pressure exceeded $600 \mathrm{MPa}$ or the pressure holding time reached $1 \mathrm{~h}$. Volume reduction induced by HHP can cause changes in chemical reaction equilibrium [6] and in the physicochemical characteristic of red wine; namely, colour intensity and phenolic compound content decreased. As to sensory properties, the sour and fruity aroma of the wine weakened after $2 \mathrm{~h}$ of pressurisation whereas the intensity of several gustative attributes, including astringency, alcohol content, and bitter taste, were slightly enhanced. Pressure treatments at 400-500 $\mathrm{MPa}$ for $5 \mathrm{~min}$ have influenced red wine physicochemical and sensory characteristics in the long-run; namely, it showed a brighter orange-red colour, the antioxidant capacity, the total phenolic content, and anthocyanin content decreased due to an increase in condensation reactions of phenolic compounds during wine ageing [11]. It is difficult to generalise the effect of HHP processing for different food products because of their complexity. Little research has been conducted using HHP to treat wines [12,13]. Reports indicate that pressures between $300 \mathrm{MPa}$ and $500 \mathrm{MPa}$ for 5 to $15 \mathrm{~min}$ can inactivate bacteria and yeasts in red and white wines without causing significant sensory changes [4, 14]. Sweet wines containing Saccharomyces cerevisiae and/or lactic acid bacteria were successfully stabilised by HHP at $350-600 \mathrm{MPa}[15,16]$. In a study conducted by LonvaudFunel et al. [16] and Delfini et al. [15], the optimal conditions for pressure, time, and temperature were established to achieve microbiological and biochemical stability in wines with different levels of microorganism inoculation and $\mathrm{SO}_{2}$.

To use HHP on wine, more studies are needed about chemical reactions caused by HHP, especially how it affects the physicochemical sensory and quality properties of young white wine. Therefore, the aim of the present study was to investigate the effects of high hydrostatic pressure on oenological and quality properties of young white wine (Sauvignon blanc). The total phenolic and flavonoid content, antioxidant capacity, colour, aroma components, and sensory properties, as well as the possible variations in physicochemical parameters, were evaluated.

\section{Materials and Methods}

2.1. Reagents and Other Materials. Trolox ${ }^{\circledR}$ (6-hydroxy-2,5,7, 8-tetramethylchroman-2-carboxylic acid), methanol (Tedia, USA), DPPH (2,2-diphenyl-1-picryhydrazyl), and Folin-Ciocalteau phenol reagents were from Merck (Darmstadt, Germany). Milli-Q water was obtained through a Millipore filtration system (Millipore Co., USA). All standards were purchased from Aldrich (Milwaukee, WI, USA) and Fluka (Buchs, Switzerland). Purity of all standards was above $99 \%$. A Folin-Ciocalteau (FC) reagent was from Merck (Merck $\mathrm{KGaA}$, Germany), as well as $0.1 \mathrm{~N}$ standard solution of sodium hydroxide, $30 \%$ solution $\mathrm{H}_{2} \mathrm{O}_{2}$, copper sulphate, sulphuric acid, and hydrochloric acid (Merck, Darmstadt, Germany).

2.2. Wine Samples. The young white wine (Sauvignon blanc) used in this study was acquired from the Veramonte Winery's 2012 harvest in the Casablanca Valley, Chile. The wine contained 15-20 ppm of free sulphur dioxide $\left(\mathrm{SO}_{2}\right)$, but it did not contain bentonite. Once fermentation was completed, the white wine was packaged in 60 -L polyethylene drums and stored until the HHP treatment in the dark. All the wine analysis was realized in triplicate.

2.3. High Hydrostatic Pressure (HHP) Treatment. Packaged white wine was pressurised in a 2 -L pressure unit (Avure Technologies Incorporated, Kent, WA, USA) with a $700 \times$ $600 \mathrm{~mm}$ cylinder. In all cases, water was used as the pressuretransmitting medium; white wine was treated at $400 \mathrm{MPa}$, $450 \mathrm{MPa}$, and $500 \mathrm{MPa}$ for $5 \mathrm{~min}, 10 \mathrm{~min}$, and $15 \mathrm{~min}$ at ambient temperature and compared to untreated wine. Pressurised and untreated wine samples were stored at $16^{\circ} \mathrm{C}$ until physicochemical characterisation was performed.

2.4. Physicochemical Analysis. The values of the physicochemical parameters, such as soluble solid, $\mathrm{pH}$, total acidity, tartaric acid, and degree of alcohol, were determined according to the Official Newspaper of the European Communities 1990 [17]. Turbidity was measured with a turbidimeter $(\mathrm{HACH} 2100 \mathrm{P})$ at $20^{\circ} \mathrm{C}$. Total and free $\mathrm{SO}_{2}$ were measured by the aspiration/oxidation method, also known as Rankin's method. Finally, determination of reducing sugar was by Fehling's method. Pectin content was qualitatively determined with a Novo-Test ${ }^{\circledR}$ kit (Novozymes, Switzerland).

2.5. Colour Measurement. The colour of the white wine samples was measured with a colourimeter (HunterLab, model MiniScan XE Plus, Reston, VA, USA) after calibration with white and black glass standards. Colour was expressed as CIE coordinates of $L^{*}$ (lightness), $a^{*}$ (redness/greenness), and $b^{*}$ (yellowness/blueness) with illuminant $\mathrm{D}_{65}$ and observer $10^{\circ}$ standardisation. Three replicate measurements were performed, and the results averaged. The colourimeter yielded $L^{*}, a^{*}$, and $b^{*}$ values $[18,19]$ that were converted into 
whiteness index (WI) values according to the expression $\mathrm{WI}=100-\left[\left(100-L^{*}\right)^{2}+\left(a^{*}\right)^{2}+\left(b^{*}\right)^{2}\right]^{0.5}$. Parameters were also correlated with colour perception; chroma $\left(C^{*}{ }_{a b}\right)$ and hue angle $\left(h_{a b}\right)$ polar coordinates were determined according to the equations $C^{*}{ }_{a b}=\left(a^{* 2}+b^{* 2}\right)^{0.5}$ and $h_{a b}=\tan ^{-1}\left(b^{*} / a^{*}\right)$. Chroma $\left(C^{*}{ }_{a b}\right)$ is the quantitative attribute of colourfulness that enables the characterisation of differences in the grey colour between samples exhibiting the same lightness for each hue. Hue $\left(h_{a b}\right)$, regarded as the qualitative attribute of colour, is the parameter from which colours are traditionally defined, for example, reddish or yellowish. It is the attribute that specifically allows a colour to be differentiated from a grey colour with the same lightness.

2.6. Determination of Total Antioxidant Capacity by 2,2diphenyl-1-picrylhydrazyl Assay (DPPH). Total antioxidant capacity was determined according to Fernández-Pachón et al. [20] with slight modifications. Total antioxidant capacity of the DPPH assay for the white wine samples was expressed

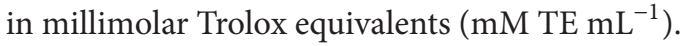

2.7. Determination of Total Phenolic (TP) Content. Total phenolic content was determined by a spectrophotometer assay (Spectronic ${ }^{\circledR} 20$ Genesys $^{\mathrm{TM}}$, IL, USA) with Folin-Ciocalteau reagent (FC) in agreement with previous work [21]. The results were expressed as $\mathrm{mg}$ gallic acid $(\mathrm{GA}) \mathrm{mL}^{-1}$ in white wine.

2.8. Determination of Flavonoid Content. Total flavonoids were measured by a modified colourimetric assay developed by Dini et al. 2010 [22]. Results were expressed as mg quercetin equivalents $(\mathrm{QE}) \mathrm{mL}^{-1}$ in white wine.

\subsection{Determination of Volatile Compounds}

2.9.1. Sample Preparation. The solid-phase microextraction (SPME) method was used to extract analytes from the white wine. A 3-mL volume of white wine was placed in a $10-\mathrm{mL}$ vial that was kept at $40^{\circ} \mathrm{C}$ for $15 \mathrm{~min}$ at $650 \mathrm{rpm}$ agitation. A bipolar polydimethylsiloxane fibre, coated with Carbowax and divinylbenzene (PDMS/CW/DVB, Supelco), was then exposed to the vial headspace for $15 \mathrm{~min}$. The SPME fibre was placed in the heated injection port of the gas chromatograph at $250^{\circ} \mathrm{C}$. The volatile compounds were driven to the test chamber using a constant gas flow of $150 \mathrm{~mL} \mathrm{~min}^{-1}$ (air $100 \mathrm{~mL} \mathrm{~min}^{-1}$, nitrogen $50 \mathrm{~mL} \mathrm{~min}^{-1}$ ). White wine was measured by gas chromatography (GC).

2.10. Gas Chromatography (GC) Analysis. An Agilent Technologies gas chromatograph (model 6890N) with an autosampler (7683B series) was used to determine aromatic components. A $30-\mathrm{m}$ long DB-wax capillary column with $0.25 \mathrm{~mm}$ internal diameter and $0.25 \mu \mathrm{m}$ film was used. The carrier gas was hydrogen with 7.5 psi pressure, flow rate of $1.3 \mathrm{~mL} \mathrm{sec}^{-1}$, and velocity of $37 \mathrm{~cm} \mathrm{sec}^{-1}$. The injector temperature was $200^{\circ} \mathrm{C}$, split $5: 1$, and the white wine volume was $0.2 \mu \mathrm{L}$. A flame ionisation detector (FID) was used at $250^{\circ} \mathrm{C}$ with a hydrogen flow rate of $40 \mathrm{~mL} \mathrm{~min}^{-1}$ and air flow rate of $450 \mathrm{~mL} \mathrm{~min}^{-1}$. The white wine was incubated for $1 \mathrm{~min}$ at $35^{\circ} \mathrm{C}$ followed by a two-part gradient from $35^{\circ} \mathrm{C}$ to $90^{\circ} \mathrm{C}$ with a ramp rate of $15^{\circ} \mathrm{C} \mathrm{min}-1$ and from $90^{\circ} \mathrm{C}$ to $190^{\circ} \mathrm{C}$ with a ramp rate of $40^{\circ} \mathrm{C} \mathrm{min}^{-1}$. Finally, the temperature was maintained at $190^{\circ} \mathrm{C}$ for $3 \mathrm{~min}$. Volatile compounds were identified with the NIST library while quantification was performed from the calibration curves of the respective standards in a solution prepared at different concentration levels.

2.11. Sensory Analysis. A panel of eight judges participated in the sensory evaluation (five men and three women between 28 and 54 year of age) from the Cooperativa Agrícola Pisquera Elqui Ltda. (CAPEL) Sensory Laboratory in Chile. All the panellists were trained according to ISO guidelines [23] and were familiar with the sensory evaluation of different types of wine.

Quantitative descriptive analysis was used to determine the differences in the sensory characteristics among HHPtreated and untreated wine samples. A round-table session was held to generate the vocabulary of sensory attributes [24] prior to the evaluation sessions. All the wine samples $(n=10)$ were evaluated by every panellist. Nine attributes associated with wine appearance, odour, and taste were selected by consensus to describe the HHP-treated wines. Definitions and anchors of sensory attributes used in the descriptive analysis of HHP-treated wines are shown in Table 1. A continuous unstructured graphical scale was used by the panellists to evaluate the intensity of each sensory attribute. The scale was $10-\mathrm{cm}$ long and vertically anchored at each end. The left side of each scale represented the lowest intensity of the sensory attribute while the right side was the highest intensity. Results were converted into numerical values (from 0 to 10 units) after the evaluation.

White wine tasting was carried out in a sensory laboratory with facilities satisfying the requirements of ISO standards [25]. For tasting, $20 \mathrm{~mL}$ of each white wine sample was coded with a three-digit random number and presented to the panellists. Along with the samples, a bottle of spring water was provided for palate cleansing after each sample. Wine sample assessment was duplicated.

2.12. Statistical Analysis. An analysis of variance (ANOVA) was performed using Statgraphics Centurion XVI (Statistical Graphics Corp., Herndon, USA) which also detected significant differences among treatments. Significance testing was performed by Fisher's test; differences were statistically significant when $p \leq 0.05$. Pearson's correlation between instrumental and sensory data was also calculated.

\section{Results and Discussion}

3.1. Physicochemical Properties. Control white wine values were similar and comparable to those published in the literature [26]. White wine samples that were pressure-treated at $300 \mathrm{MPa}, 400 \mathrm{MPa}$, and $500 \mathrm{MPa}$ exhibited physicochemical properties similar to the control (untreated wine). Soluble solids ( ${ }^{\circ}$ Brix), $\mathrm{pH}$, turbidity, tartaric acid, reducing sugar 
TABLE 1: Definitions and anchors of sensory attributes used in the descriptive analysis of HHP-treated wine.

\begin{tabular}{lcc}
\hline Attribute & Definition & Anchoring points \\
\hline Appearance & & Light yellow-dark yellow \\
Color & Intensiveness of the yellow color & Dull-clear \\
Clarity & Lack of cloudiness & \\
Odour & Odour characteristics for the alcohol products \\
Alcoholic & Typical odour for ripe fruits & Imperceptible, very intensive \\
Fruity & Hydrogen sulfide, sulphur dioxide, acetic & Imperceptible, very intensive \\
Defects & Sensation of mouth getting drying (coming from tannins) & Imperceptible, very intensive \\
Taste & Typical taste for alcohol & Imperceptible, very intensive \\
Astringent & Typical fruits for ripe fruits & Imperceptible, very intensive \\
Alcoholic & Imperceptible, very intensive \\
Fruity & Overall quality of the sample compared to untreated sample & Imperceptible, very intensive \\
Overall quality & &
\end{tabular}

TABLE 2: Effects of HHP on physicochemical parameters.

\begin{tabular}{|c|c|c|c|c|c|c|}
\hline \multirow[b]{2}{*}{ Treatments } & \multicolumn{6}{|c|}{ Parameters } \\
\hline & $\begin{array}{c}\text { Soluble solids } \\
\left.\text { ( }{ }^{\circ} \text { Brix }\right)\end{array}$ & $\mathrm{pH}$ & Turbidity (NTU) & $\begin{array}{l}\text { Tartaric acid } \\
\left(\mathrm{g} \mathrm{L}^{-1}\right)\end{array}$ & $\begin{array}{l}\text { Reducing sugar } \\
\qquad\left(\mathrm{g} \mathrm{L}^{-1}\right)\end{array}$ & $\begin{array}{c}\text { Alcoholic } \\
\text { degree }(\% \mathrm{v} / \mathrm{v})\end{array}$ \\
\hline Untreated (control) & $7.06 \pm 0.03^{\mathrm{a}}$ & $3.24 \pm 0.01^{\mathrm{a}}$ & $13.67 \pm 0.15^{\mathrm{a}}$ & $5.96 \pm 0.04^{\mathrm{a}}$ & $1.36 \pm 0.00^{\mathrm{a}}$ & $10.48 \pm 0.18^{\mathrm{a}}$ \\
\hline $300 \mathrm{MPa} / 5 \mathrm{~min}$ & $7.09 \pm 0.02^{\mathrm{a} . \mathrm{A}}$ & $3.26 \pm 0.01^{\mathrm{a} . \mathrm{A}}$ & $15.37 \pm 0.23^{\mathrm{b} . \mathrm{B}}$ & $6.09 \pm 0.03^{\mathrm{a} . \mathrm{A}}$ & $1.36 \pm 0.00^{\mathrm{a} . \mathrm{A}}$ & $12.75 \pm 0.07^{\mathrm{b} . \mathrm{A}}$ \\
\hline $300 \mathrm{MPa} / 10 \mathrm{~min}$ & $7.06 \pm 0.01^{\mathrm{a} . \mathrm{A}}$ & $3.24 \pm 0.70^{\mathrm{a} . \mathrm{A}}$ & $13.90 \pm 0.02^{\mathrm{a} . \mathrm{A}}$ & $6.97 \pm 0.06^{\mathrm{d} . \mathrm{B}}$ & $1.36 \pm 0.00^{\mathrm{a} . \mathrm{A}}$ & $12.75 \pm 0.26^{\mathrm{b} . \mathrm{A}}$ \\
\hline $300 \mathrm{MPa} / 15 \mathrm{~min}$ & $7.04 \pm 0.02^{\mathrm{a} . \mathrm{A}}$ & $3.24 \pm 0.01^{\mathrm{a} . \mathrm{A}}$ & $14.47 \pm 0.15^{\mathrm{b} . \mathrm{A}}$ & $7.36 \pm 0.05^{\text {d.C }}$ & $1.37 \pm 0.00^{\mathrm{a} . \mathrm{A}}$ & $12.63 \pm 0.21^{\mathrm{b} . \mathrm{A}}$ \\
\hline $400 \mathrm{MPa} / 5 \mathrm{~min}$ & $7.08 \pm 0.02^{\mathrm{a} . \mathrm{A}}$ & $3.27 \pm 0.02^{\mathrm{a} . \mathrm{A}}$ & $15.17 \pm 0.25^{\mathrm{b} . \mathrm{B}}$ & $5.00 \pm 0.02^{c . D}$ & $1.38 \pm 0.00^{\mathrm{a} . \mathrm{A}}$ & $12.80 \pm 0.42^{\text {b.A }}$ \\
\hline $400 \mathrm{MPa} / 10 \mathrm{~min}$ & $7.09 \pm 0.01^{\mathrm{a} . \mathrm{A}}$ & $3.26 \pm 0.00^{\mathrm{a} . \mathrm{A}}$ & $13.33 \pm 0.67^{\mathrm{a} . \mathrm{A}}$ & $5.99 \pm 0.02^{\mathrm{a} . \mathrm{E}}$ & $1.38 \pm 0.00^{\mathrm{a} . \mathrm{A}}$ & $13.70 \pm 0.14^{\text {c.C }}$ \\
\hline $400 \mathrm{MPa} / 15 \mathrm{~min}$ & $7.10 \pm 0.01^{\mathrm{a} . \mathrm{A}}$ & $3.25 \pm 0.01^{\mathrm{a} . \mathrm{A}}$ & $12.97 \pm 0.86^{\mathrm{a} . \mathrm{A}}$ & $6.05 \pm 0.09^{\mathrm{a} . \mathrm{A}}$ & $1.36 \pm 0.00^{\mathrm{a} . \mathrm{A}}$ & $12.83 \pm 0.32^{\text {b.A }}$ \\
\hline $500 \mathrm{MPa} / 5 \mathrm{~min}$ & $7.16 \pm 0.02^{\text {b.B }}$ & $3.25 \pm 0.01^{\mathrm{a} . \mathrm{A}}$ & $13.93 \pm 0.25^{\mathrm{a} . \mathrm{A}}$ & $6.93 \pm 0.01^{\text {b. }}$ & $1.38 \pm 0.00^{\mathrm{a} . \mathrm{A}}$ & $12.55 \pm 0.07^{\text {b.A }}$ \\
\hline $500 \mathrm{MPa} / 10 \mathrm{~min}$ & $7.08 \pm 0.01^{\mathrm{a} . \mathrm{A}}$ & $3.25 \pm 0.00^{\mathrm{a} . \mathrm{A}}$ & $17.57 \pm 0.67^{\text {c.C }}$ & $5.92 \pm 0.02^{\mathrm{a} . \mathrm{F}}$ & $1.35 \pm 0.00^{\mathrm{a} . \mathrm{A}}$ & $12.15 \pm 1.35^{\text {b. } A B}$ \\
\hline $500 \mathrm{MPa} / 15 \mathrm{~min}$ & $7.08 \pm 0.01^{\mathrm{a} . \mathrm{A}}$ & $3.25 \pm 0.01^{\mathrm{a} . \mathrm{A}}$ & $34.10 \pm 0.20^{\mathrm{d} . \mathrm{D}}$ & $5.21 \pm 0.02^{\mathrm{d} . \mathrm{G}}$ & $1.35 \pm 0.00^{\mathrm{aA}}$ & $12.65 \pm 0.07^{\mathrm{b} . \mathrm{A}}$ \\
\hline
\end{tabular}

values, and degree of alcohol are shown in Table 2. The ${ }^{\circ}$ Brix, $\mathrm{pH}$, tartaric acid, and reducing sugar showed no significant changes when the pressure level and holding time increased. The degree of alcohol (\% v/v) showed a significant difference; it increased for all the pressure levels and holding times when it was compared to the control; however, this difference was only small alcohol degrees $\left(2-3^{\circ}\right)$, which is especially advantageous because wines and other alcoholic beverages are commercialised and categorised by alcohol content. As to turbidity, an increase was observed in treated white wine at $500 \mathrm{MPa}$ for 10 and $15 \mathrm{~min}$ as compared to the control. The greatest change in turbidity (149\%) was observed after treatment with $500 \mathrm{MPa}$ for $15 \mathrm{~min}$. This increase in turbidity could be caused by residual pectin in the wine that coagulated and was not removed during final filtration. This was demonstrated by the qualitative assay of pectin shown in Figure 1.

Similar results for $\mathrm{pH}$ and tartaric acid ( $\mathrm{g} \mathrm{L}^{-1}$ wine) were reported by Kallithraka et al. [27] for white wine varieties. Lonvaud-Funel et al. [16] reported $3.93 \mathrm{pH}$ for Sauternes white wine; Delfini et al. [15] reported $3.0 \mathrm{pH}$ for the Barbera grape variety, and the same authors reported $3.4 \mathrm{pH}$ for sparkling white wine treated by HHP at $600 \mathrm{MPa}$ for $2 \mathrm{~min}$.

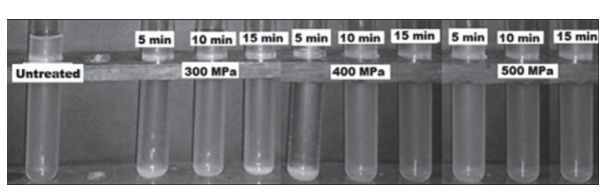

FIGURE 1: White wine pectin assay (Sauvignon blanc) by HHP treatment.

Their results demonstrated that these parameters experienced little change as a result of applying HHP; this is similar to the results found in the present study (Table 2 ). The retention of the physicochemical properties of white wine despite the HHP treatment is advantageous because these properties might affect the product's sensory quality.

Total $\mathrm{SO}_{2}$ (Table 3) was determined for two reasons, (a) to control its concentration ( $<200 \mathrm{mg} / \mathrm{L}$ for white wines) because wine consumption has been related to various allergic reactions in numerous individuals [28, 29] and (b) to monitor its concentration in wine during HHP treatments because $\mathrm{SO}_{2}$ has an antimicrobial and preservative effect on wine. 
TABLE 3: Effects of HHP on free and total $\mathrm{SO}_{2}$.

\begin{tabular}{|c|c|c|}
\hline \multirow{2}{*}{ Treatments } & \multicolumn{2}{|c|}{ Parameters } \\
\hline & $\mathrm{SO}_{2}$ Free $\left(\mathrm{mg} \mathrm{L}^{-1}\right)$ & $\mathrm{SO}_{2}$ total $\left(\mathrm{mg} \mathrm{L}^{-1}\right)$ \\
\hline Untreated (control) & $27.73 \pm 0.76^{\mathrm{a}}$ & $88.75 \pm 1.48^{\mathrm{a}}$ \\
\hline $300 \mathrm{MPa} / 5 \mathrm{~min}$ & $29.60 \pm 7.92^{\mathrm{a} . \mathrm{AB}}$ & $91.20 \pm 3.92^{\text {ab.A }}$ \\
\hline $300 \mathrm{MPa} / 10 \mathrm{~min}$ & $30.67 \pm 2.57^{\mathrm{a} . \mathrm{BC}}$ & $93.60 \pm 3.39^{\mathrm{b} . \mathrm{A}}$ \\
\hline $300 \mathrm{MPa} / 15 \mathrm{~min}$ & $39.20 \pm 3.39^{\mathrm{b} . \mathrm{C}}$ & $104.80 \pm 1.13^{c . B}$ \\
\hline $400 \mathrm{MPa} / 5 \mathrm{~min}$ & $24.53 \pm 4.03^{\mathrm{a} . \mathrm{A}}$ & $88.00 \pm 2.26^{\mathrm{a} . \mathrm{A}}$ \\
\hline $400 \mathrm{MPa} / 10 \mathrm{~min}$ & $23.20 \pm 0.92^{\mathrm{a} . \mathrm{A}}$ & $87.20 \pm 5.05^{\mathrm{a} . \mathrm{A}}$ \\
\hline $400 \mathrm{MPa} / 15 \mathrm{~min}$ & $30.67 \pm 5.90^{\text {ab.BC }}$ & $107.90 \pm 5.23^{\mathrm{c} . \mathrm{B}}$ \\
\hline $500 \mathrm{MPa} / 5 \mathrm{~min}$ & $27.75 \pm 9.05^{\mathrm{a} . \mathrm{AB}}$ & $91.60 \pm 3.68^{\mathrm{ab} . \mathrm{AB}}$ \\
\hline $500 \mathrm{MPa} / 10 \mathrm{~min}$ & $22.47 \pm 2.00^{\mathrm{a} . \mathrm{A}}$ & $83.30 \pm 2.40^{\mathrm{a} . \mathrm{A}}$ \\
\hline $500 \mathrm{MPa} / 15 \mathrm{~min}$ & $44.80 \pm 9.05^{\mathrm{c} . \mathrm{D}}$ & $118.40 \pm 2.36^{\text {d.C }}$ \\
\hline
\end{tabular}

Free $\mathrm{SO}_{2}$ content increased $41 \%, 11 \%$, and $62 \%$ for $300 \mathrm{MPa}, 400 \mathrm{MPa}$, and $500 \mathrm{MPa}$ at $15 \mathrm{~min}$, respectively, as compared to the control (Table 3); furthermore, total $\mathrm{SO}_{2}$ increased $18 \%, 21 \%$, and $33 \%$ at $300 \mathrm{MPa}, 400 \mathrm{MPa}$, and $500 \mathrm{MPa}$ at $15 \mathrm{~min}$, respectively, as compared to the control one. Delfini et al. [15] reported total $\mathrm{SO}_{2}$ content from two wines, muscatel $\left(64 \mathrm{mg} \mathrm{L}^{-1}\right.$ and $\left.102.4 \mathrm{mg} \mathrm{L}^{-1}\right)$ and sparkling wine of the Asti variety $\left(64 \mathrm{mg} \mathrm{L}^{-1}\right)$; free and total $\mathrm{SO}_{2}$ content in white wine samples were within the range of values reported by these authors. Small amounts of sulphites can form naturally in wine during fermentation [30], but vintners commonly add 30-90 ppm of additional sulphites during production [31] to prevent spoilage and enhance the ageing potential [32]. High hydrostatic pressure could help the processing of the wine to reduce amount of $\mathrm{SO}_{2}$ added. Recently, the wine industry is challenged to meet consumers' demands of reducing the amount of $\mathrm{SO}_{2}$ added to wine, especially since it has been associated with some health risks such as allergic reactions incurred by sulphite-sensitive individuals. The addition of $\mathrm{SO}_{2}$ is meant to behave as a preserver to inhibit the proliferation of yeast and prevent the undesirable aroma caused by oxidation reaction with the free acetaldehyde present in the wine [33]. However, HHP has demonstrated a strong antimicrobial effect decreasing the proliferation of yeast and preventing the oxidation reactions during storage that can be appreciated by keeping the original colour in the wine and improving both the aroma and the perception of the young white wine [4].

High hydrostatic pressure could help the wine industry to reduce $\mathrm{SO}_{2}$ levels. The increase of free and total $\mathrm{SO}_{2}$ content is because HHP can deprotonate charged groups to disrupt salt bridges and hydrophobic bonds in cellular membranes which can lead to higher permeability $[34,35]$. Furthermore, $\mathrm{SO}_{2}$ from wine was significantly influenced $(p \leq 0.05)$ by the high-pressure treatment. The pressure equilibrium between the inside and outside of the cells could occur over a very short time. Under these circumstances, solvent diffusion speed is high and extraction yield can reach its highest value very rapidly [36].
3.2. Effect of HHP on Colour Parameters of White Wine. Colour is one of the most important properties of wine and provides considerable information about its overall quality. The evaluation of white wine chromatic characteristics during the HHP treatment is shown in Table 4. Some of the wine chromatic characteristics were not significantly $(p \leq 0.05)$ affected by HHP.

The lightness $\left(L^{*}\right)$ value decreased when pressure increased, which indicates that HHP-treated wine samples were less bright than the control. The HHP-treated white wine had significantly higher $a^{*}$ (redness) and lower $b^{*}$ (yellowness) values than the control values (Table 4 ). These results were higher than the results from the UV-VIS irradiationtreated white wine reported by Falguera et al. [37], and they were lower than those reported by Gómez-Míguez et al. [38] for untreated white wines produced from grapes of the variety $V$. vinifera L. cv. Zalema. Hue angle and chroma are both related to human colour perception. Chroma is defined as the chromatic intensity compared to pure white. The HHP treatment led to a significant decrease in $C^{*}$ (chroma) value when compared to untreated wine. Hue is the colour attribute related to perceived colours, that is to say, red, yellow, green, blue, or a combination of these. In the present study, $h_{a b}$ (hue angle, grade) parameter does not show any significant difference between HHP-treated and untreated white wine samples expressed in CIELAB units. Therefore, wine chromatic characteristics $\left(a^{*}\right.$ and $\left.b^{*}\right)$ changed slightly after applying HHP, but these changes could not be visually perceived because they were less than $5 \%$.

3.3. Total Phenolic (TP) Content, Flavonoid Content, and Antioxidant Capacity (DPPH Assay). Phenolic compounds are one of the most numerous and widely distributed substances of plant origin; they are therefore an integral part of the human diet. These compounds are also very important to define wine quality and contribute to organoleptic characteristics, including appearance, odour, and mouthfeel sensations [9].

Total phenolic and flavonoid contents in white wine after the HHP treatment are shown in Table 5; there were no significant differences between the flavonoid content values of wines treated with HHP for all the pressures and times as compared to the control. TP content showed a significant difference at $300 \mathrm{MPa}$ for 10 and $15 \mathrm{~min}, 400 \mathrm{MPa}$ for $5 \mathrm{~min}$ with a decrease $7 \%$ and $14 \%$ and an increase of $5 \%$, respectively, as compared to the control. These results confirm that HHP does not severely damage the phenolic content of white wines. A different effect was observed for the antioxidant capacity expressed as $\mathrm{DPPH}$, which significantly increased in white wine treated at $300 \mathrm{MPa}$ and $400 \mathrm{MPa}$ for all the times, but it did not differ significantly with the control at $500 \mathrm{MPa}$. The observed decrease in DPPH levels can be associated with the generation of high-reactive radicals during pressurisation and increased polyphenol oxidation [39].

The values obtained in the present study are slightly lower than those found by Ferreira-Lima et al. [40] in Goethe white wines, Mitić et al. [41] in varieties of Serbian white wines, and Roussis et al. [42] in some Greek wines. 
TABLE 4: Effects of HHP oncolour parameters of white wine.

\begin{tabular}{|c|c|c|c|c|c|c|}
\hline \multirow{2}{*}{ Treatments } & \multicolumn{6}{|c|}{ Parameters } \\
\hline & $L^{*}$ & $a^{*}$ & $b^{*}$ & WI (white index) & $C^{*}$ (chroma) & $h$ (tone) \\
\hline Untreated (control) & $73.28 \pm 0.19^{\mathrm{a}}$ & $-1.03 \pm 0.19^{\mathrm{a}}$ & $7.52 \pm 0.19^{\mathrm{ab}}$ & $72.22 \pm 0.05^{\mathrm{a}}$ & $7.59 \pm 0.03^{\mathrm{a}}$ & $41.10 \pm 0.04^{\mathrm{ab}}$ \\
\hline $300 \mathrm{MPa} / 5 \mathrm{~min}$ & $72.70 \pm 0.30^{\mathrm{abc}}$ & $-0.97 \pm 0.00^{\mathrm{de}}$ & $6.97 \pm 0.27^{c}$ & $71.80 \pm 0.10^{\mathrm{abc}}$ & $7.04 \pm 0.06^{\mathrm{b}}$ & $41.04 \pm 0.02^{\mathrm{ab}}$ \\
\hline $300 \mathrm{MPa} / 10 \mathrm{~min}$ & $72.91 \pm 0.01^{\mathrm{abc}}$ & $-1.00 \pm 0.01^{\mathrm{cd}}$ & $7.12 \pm 0.17^{\mathrm{bc}}$ & $71.97 \pm 0.04^{\mathrm{abc}}$ & $7.19 \pm 0.02^{b}$ & $41.00 \pm 0.02^{\mathrm{ab}}$ \\
\hline $300 \mathrm{MPa} / 15 \mathrm{~min}$ & $72.05 \pm 0.01^{\mathrm{c}}$ & $-0.89 \pm 0.01^{\mathrm{e}}$ & $5.92 \pm 0.06^{\mathrm{e}}$ & $71.42 \pm 0.05^{\mathrm{c}}$ & $6.00 \pm 0.16^{\mathrm{d}}$ & $41.73 \pm 0.10^{\mathrm{a}}$ \\
\hline $400 \mathrm{MPa} / 5 \mathrm{~min}$ & $72.65 \pm 0.46^{\mathrm{abc}}$ & $-0.98 \pm 0.01^{\mathrm{cd}}$ & $6.72 \pm 0.44^{\mathrm{cd}}$ & $71.82 \pm 0.03^{\mathrm{abc}}$ & $6.79 \pm 0.12^{\mathrm{bc}}$ & $40.85 \pm 0.12^{\mathrm{ab}}$ \\
\hline $400 \mathrm{MPa} / 10 \mathrm{~min}$ & $73.47 \pm 0.82^{\mathrm{a}}$ & $-1.01 \pm 0.01^{\mathrm{ab}}$ & $7.12 \pm 0.17^{\mathrm{a}}$ & $72.51 \pm 0.05^{\mathrm{a}}$ & $7.19 \pm 0.02^{\mathrm{b}}$ & $40.96 \pm 0.15^{\mathrm{ab}}$ \\
\hline $400 \mathrm{MPa} / 15 \mathrm{~min}$ & $72.83 \pm 0.36^{\mathrm{abc}}$ & $-1.01 \pm 0.02^{\mathrm{ab}}$ & $7.01 \pm 0.35^{c}$ & $71.92 \pm 0.10^{\mathrm{abc}}$ & $7.08 \pm 0.05^{\mathrm{b}}$ & $40.90 \pm 0.13^{\mathrm{ab}}$ \\
\hline $500 \mathrm{MPa} / 5 \mathrm{~min}$ & $72.94 \pm 0.38^{\mathrm{ab}}$ & $-0.99 \pm 0.04^{\mathrm{cd}}$ & $7.51 \pm 0.34^{\mathrm{a}}$ & $71.90 \pm 0.10^{\mathrm{ab}}$ & $7.57 \pm 0.01^{\mathrm{a}}$ & $41.25 \pm 0.05^{\mathrm{b}}$ \\
\hline $500 \mathrm{MPa} / 10 \mathrm{~min}$ & $72.94 \pm 1.09^{\mathrm{ab}}$ & $-0.99 \pm 0.02^{\mathrm{cd}}$ & $6.83 \pm 0.41^{c}$ & $72.07 \pm 0.05^{\mathrm{ab}}$ & $6.90 \pm 0.10^{\mathrm{b}}$ & $40.88 \pm 0.15^{\mathrm{ab}}$ \\
\hline $500 \mathrm{MPa} / 15 \mathrm{~min}$ & $72.35 \pm 0.11^{\mathrm{bc}}$ & $-0.94 \pm 0.02^{\mathrm{d}}$ & $6.31 \pm 0.10^{\mathrm{de}}$ & $71.62 \pm 0.05^{\mathrm{bc}}$ & $6.38 \pm 0.15^{\mathrm{c}}$ & $40.76 \pm 0.13^{\mathrm{ab}}$ \\
\hline
\end{tabular}

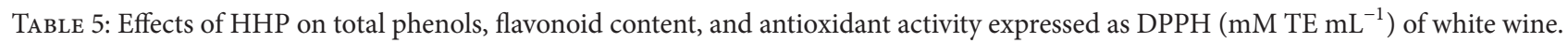

\begin{tabular}{lccc}
\hline Treatments & $\begin{array}{c}\text { Total phenolic } \\
\left(\mathrm{mg} \mathrm{AG} \mathrm{mL}^{-1}\right)\end{array}$ & $\begin{array}{c}\text { Parameters } \\
\text { Flavonoid } \\
\left(\mathrm{mg} \mathrm{quercetin} \mathrm{mL}^{-1}\right)\end{array}$ & $\begin{array}{c}\text { DPPH } \\
\left(\mathrm{mM} \mathrm{TE} \mathrm{mL}^{-1}\right)\end{array}$ \\
\hline Untreated (control) & $0.241 \pm 0.000^{\mathrm{ab}}$ & $0.058 \pm 0.000^{\mathrm{a}}$ & $0.510 \pm 0.000^{\mathrm{a}}$ \\
$300 \mathrm{MPa} / 5 \mathrm{~min}$ & $0.239 \pm 0.002^{\mathrm{a}}$ & $0.057 \pm 0.008^{\mathrm{a}}$ & $0.633 \pm 0.003^{\mathrm{b}}$ \\
$300 \mathrm{MPa} / 10 \mathrm{~min}$ & $0.234 \pm 0.008^{\mathrm{a}}$ & $0.057 \pm 0.003^{\mathrm{a}}$ & $0.647 \pm 0.013^{\mathrm{b}}$ \\
$300 \mathrm{MPa} / 15 \mathrm{~min}$ & $0.237 \pm 0.003^{\mathrm{a}}$ & $0.056 \pm 0.003^{\mathrm{a}}$ & $0.651 \pm 0.018^{\mathrm{b}}$ \\
$400 \mathrm{MPa} / 5 \mathrm{~min}$ & $0.253 \pm 0.005^{\mathrm{b}}$ & $0.055 \pm 0.003^{\mathrm{a}}$ & $0.673 \pm 0.007^{\mathrm{b}}$ \\
$400 \mathrm{MPa} / 10 \min$ & $0.247 \pm 0.008^{\mathrm{ab}}$ & $0.058 \pm 0.001^{\mathrm{a}}$ & $0.681 \pm 0.009^{\mathrm{b}}$ \\
$400 \mathrm{MPa} / 15 \min$ & $0.247 \pm 0.004^{\mathrm{ab}}$ & $0.063 \pm 0.000^{\mathrm{ab}}$ & $0.636 \pm 0.076^{\mathrm{b}}$ \\
$500 \mathrm{MPa} / 5 \mathrm{~min}$ & $0.241 \pm 0.007^{\mathrm{ab}}$ & $0.062 \pm 0.000^{\mathrm{ab}}$ & $0.523 \pm 0.033^{\mathrm{a}}$ \\
$500 \mathrm{MPa} / 10 \mathrm{~min}$ & $0.246 \pm 0.001^{\mathrm{ab}}$ & $0.060 \pm 0.001^{\mathrm{ab}}$ & $0.495 \pm 0.008^{\mathrm{a}}$ \\
$500 \mathrm{MPa} / 15 \mathrm{~min}$ & $0.242 \pm 0.001^{\mathrm{ab}}$ & $0.059 \pm 0.001^{\mathrm{ab}}$ & $0.512 \pm 0.021^{\mathrm{a}}$ \\
\hline
\end{tabular}

According to Le Chatelier's principle, the volume of the system tends to be reduced during the pressure-promoting period. The extraction solvent enters cells and reacts with bioactive components in this process. It is accelerated because pressurised cells increased their permeability [43]. Sulphur dioxide is an effective antioxidant which may not only suppress several nonenzymatic oxidative reactions but can also convert the oxidation products back into the reduced forms in some cases [29]. Therefore, $\mathrm{SO}_{2}$ is likely to have a negative effect on the potential oxidation of phenolic compounds during $\mathrm{HHP}$ processing. In the present study, $\mathrm{SO}_{2}$ increased when pressure and time increased (Table 2), and it could affect the interaction between $\mathrm{SO}_{2}$ and phenolic compounds.

\subsection{Semiquantitative Determination of Wine Volatile Com-} pounds (Aromatic Profile Analysis). The volatile compounds identified in white wine are shown in Table 6 . The white wine under study had 25 volatile compounds of which 18 were below the quantification limit and only seven were detected, for example, alcohols, organic acids, esters, and aldehydes.

The young white wine aroma compounds mainly came from two sources, the grapes and the microorganisms from the fermentation stages (yeasts and lactic acid bacteria). They belong to different chemical families, such as esters, acids, terpenoids, phenols, alcohols, lactones, and aldehydes. They can be influenced by several factors, for example, factors related to vineyards, such as the phytosanitary product [44, 45], cover crops [46], neighbouring plants [47], presence of exogenous substances, such as smoke [48, 49], or those provided by oak extract treatments [50-53].

Esters are the group of chemical compounds that are primarily responsible for wine aroma. A small fraction of esters come from the grapes, but the largest fraction is synthesised by yeast during alcoholic fermentation, which is then complemented by malolactic fermentation with lactic acid bacteria (LAB). Ester content in white wine accounted for approximately $65 \%$ to $76 \%$ of the total aroma fraction (Table 6). Ascetic esters of higher alcohols, such as ethyl acetate, were found in this chemical group. Of the total esters quantified in white wine, only $14 \%$ to $19 \%$ were acetates (Table 6 ), which are normally found in moderate quantities; however, they have intense, positive odours (banana, rose, acid drops, and apple) and contribute to the aromatic complexity of wines [50].

Ethyl esters, together with acetates, contribute to the typical floral and fruity aromas of young wines; they play an important role in the aroma; however, if their levels are below the $80 \mathrm{mg} \mathrm{L}^{-1}$ limit, they cause an unpleasant aroma. In spite of this, Martínez-Gil et al. [50] suggest that the wine 
TABLE 6: Effect of HHP on volatile compound content of white wine (ND = not detected).

\begin{tabular}{|c|c|c|c|c|c|c|c|}
\hline \multirow{4}{*}{ Treatments } & \multicolumn{7}{|c|}{ Volatiles compounds } \\
\hline & \multirow{3}{*}{$\begin{array}{l}\text { Aldehydes } \\
\text { Perception } \\
\text { threshold } \\
1.0 \mathrm{~g} / \mathrm{L}\end{array}$} & \multirow{3}{*}{$\begin{array}{c}\text { Ethyl acetate } \\
\text { Perception } \\
\text { threshold } \\
0.08 \mathrm{~g} / \mathrm{L}\end{array}$} & \multirow{3}{*}{$\begin{array}{l}\text { Methyl Alcohol } \\
\text { Perception } \\
\text { threshold } \\
1.5 \mathrm{~g} / \mathrm{L}\end{array}$} & \multicolumn{4}{|c|}{ Higher alcohols } \\
\hline & & & & Propanol & Isobutanol & Butanol & Isoamyl \\
\hline & & & & $\begin{array}{c}\text { Perception } \\
\text { threshold } \\
0.01 \mathrm{~g} / \mathrm{L}\end{array}$ & $\begin{array}{c}\text { Perception } \\
\text { threshold } \\
0.01 \mathrm{~g} / \mathrm{L}\end{array}$ & $\begin{array}{c}\text { Perception } \\
\text { threshold } \\
0.005 \mathrm{~g} / \mathrm{L}\end{array}$ & $\begin{array}{c}\text { Perception } \\
\text { threshold } \\
0.02 \mathrm{~g} / \mathrm{L}\end{array}$ \\
\hline $\begin{array}{l}\text { Untreated } \\
\text { (control) }\end{array}$ & $11 \pm 0.02^{\mathrm{abc}}$ & $0.51 \pm 0.03^{\mathrm{a}}$ & $0.40 \pm 0.03^{\mathrm{a}}$ & $0.35 \pm 0.03^{\mathrm{ab}}$ & $0.15 \pm 0.03^{\mathrm{a}}$ & ND & $1.37 \pm 0.03^{\mathrm{ab}}$ \\
\hline $300 \mathrm{MPa} / 5 \mathrm{~min}$ & $0.78 \pm 0.02^{\mathrm{abc}}$ & $0.51 \pm 0.03^{\mathrm{a}}$ & $0.40 \pm 0.03^{\mathrm{a}}$ & $0.35 \pm 0.03^{\mathrm{ab}}$ & $0.15 \pm 0.03^{\mathrm{a}}$ & ND & $1.37 \pm 0.03^{\mathrm{ab}}$ \\
\hline $300 \mathrm{MPa} / 10 \mathrm{~min}$ & $0.78 \pm 0.02^{\mathrm{abc}}$ & $0.51 \pm 0.03^{\mathrm{a}}$ & $0.40 \pm 0.03^{\mathrm{a}}$ & $0.35 \pm 0.03^{\mathrm{ab}}$ & $0.15 \pm 0.03^{\mathrm{a}}$ & ND & $1.37 \pm 0.03^{\mathrm{ab}}$ \\
\hline $300 \mathrm{MPa} / 15 \mathrm{~min}$ & $0.78 \pm 0.02^{\mathrm{abc}}$ & $0.51 \pm 0.03^{\mathrm{a}}$ & $0.40 \pm 0.03^{\mathrm{a}}$ & $0.35 \pm 0.03^{\mathrm{ab}}$ & $0.15 \pm 0.03^{\mathrm{a}}$ & ND & $1.37 \pm 0.03^{\mathrm{ab}}$ \\
\hline $400 \mathrm{MPpa} / 5 \mathrm{~min}$ & $0.78 \pm 0.02^{\mathrm{abc}}$ & $0.51 \pm 0.03^{\mathrm{a}}$ & $0.40 \pm 0.03^{\mathrm{a}}$ & $0.35 \pm 0.03^{\mathrm{ab}}$ & $0.15 \pm 0.03^{\mathrm{a}}$ & ND & $1.37 \pm 0.03^{\mathrm{ab}}$ \\
\hline $400 \mathrm{MPa} / 10 \mathrm{~min}$ & $0.78 \pm 0.02^{\mathrm{abc}}$ & $0.51 \pm 0.03^{\mathrm{a}}$ & $0.40 \pm 0.03^{\mathrm{a}}$ & $0.35 \pm 0.03^{\mathrm{ab}}$ & $0.15 \pm 0.03^{\mathrm{a}}$ & ND & $1.37 \pm 0.03^{\mathrm{ab}}$ \\
\hline $400 \mathrm{MPa} / 15 \mathrm{~min}$ & $0.78 \pm 0.02^{\mathrm{abc}}$ & $0.51 \pm 0.03^{\mathrm{a}}$ & $0.40 \pm 0.03^{\mathrm{a}}$ & $0.35 \pm 0.03^{\mathrm{ab}}$ & $0.15 \pm 0.03^{\mathrm{a}}$ & ND & $1.37 \pm 0.03^{\mathrm{ab}}$ \\
\hline $500 \mathrm{MPa} / 5 \mathrm{~min}$ & $0.78 \pm 0.02^{\mathrm{abc}}$ & $0.51 \pm 0.03^{\mathrm{a}}$ & $0.40 \pm 0.03^{\mathrm{a}}$ & $0.35 \pm 0.03^{\mathrm{ab}}$ & $0.15 \pm 0.03^{\mathrm{a}}$ & ND & $1.37 \pm 0.03^{\mathrm{ab}}$ \\
\hline $500 \mathrm{MPa} / 10 \mathrm{~min}$ & $0.78 \pm 0.02^{\mathrm{abc}}$ & $0.51 \pm 0.03^{\mathrm{a}}$ & $0.40 \pm 0.03^{\mathrm{a}}$ & $0.35 \pm 0.03^{\mathrm{ab}}$ & $0.15 \pm 0.03^{\mathrm{a}}$ & ND & $1.37 \pm 0.03^{\mathrm{ab}}$ \\
\hline $500 \mathrm{MPa} / 15 \mathrm{~min}$ & $0.78 \pm 0.02^{\mathrm{abc}}$ & $0.51 \pm 0.03^{\mathrm{a}}$ & $0.40 \pm 0.03^{\mathrm{a}}$ & $0.35 \pm 0.03^{\mathrm{ab}}$ & $0.15 \pm 0.03^{\mathrm{a}}$ & ND & $1.37 \pm 0.03^{\mathrm{ab}}$ \\
\hline
\end{tabular}

bouquet is better when the ethyl acetate rate is lower, as is the case in the present study. This group of compounds is not homogeneous and depends on its own acid hydrolysis and chemical esterification [54].

Only a few aldehydes were detected in the wine samples, probably because they were reduced to alcohols during fermentation. They would not have influenced the wine's aroma because their concentrations were always below the odour threshold ( $1.0 \mathrm{~g} \mathrm{~L}^{-1}$ white wine). It should be noted that HHP treatments seemed to increase aldehyde synthesis.

3.5. Sensory Analysis of HHP-Treated White Wine. The sensory properties were analysed to assess the organoleptic characteristics of the pressurised wines for aroma, colour, and taste. The influence of HHP on white wine sensory attributes and the results of the panellists' scores are displayed in Figures 2,3 , and 4 . The attributes related to white wine appearance were maintained $(p \leq 0.05)$ at the same level during pressurisation, including "colour" and "clarity" (Figure 2). Overall quality did not show a significant difference at $300 \mathrm{MPa}$ for all times when comparing it to the control (untreated white wine), but it decreased significantly at $400 \mathrm{MPa}$ and $500 \mathrm{MPa}$ for all pressurisation times. The present study is supported by Mok et al. [14], who showed a similar result where no differences were measured in the aroma, taste, mouthfeel, and overall sensory quality between the HHP-treated sample at $350 \mathrm{MPa}$ and the untreated sample and with $p>0.05$.

The olfactory (odour) attributes that were significantly $(p \leq 0.05)$ affected by HHP included alcoholic odour, fruity odour, and odour defects (Figure 3). Alcoholic odours in white wine decreased significantly as pressure increased, with the exception at $400 \mathrm{MPa}$ for $5 \mathrm{~min}$. Fruity odours in white wine decreased significantly as pressure increased whereas the odour defects increased at $400 \mathrm{MPa}$ and $500 \mathrm{MPa}$ at all pressurisation times.
When comparing the astringent tastes of the different treated wine samples to the control, there was no significant difference with the control at $300 \mathrm{MPa}$ and $400 \mathrm{MPa}$, but astringency increased significantly at $500 \mathrm{MPa}$ at all the pressurisation times.

The intensity of the alcoholic taste (Figure 4) was not significantly different between the control and $300 \mathrm{MPa}$ at the pressurisation times; however, it increased significantly at $400 \mathrm{MPa}$ at all the pressurisation times when compared to the control. Alcoholic intensity at $500 \mathrm{MPa}$ at all the pressurisation times decreased significantly when compared to the control one. The intensity of the fruity taste was significantly similar between the control and $300 \mathrm{MPa}$ at all the pressurisation times, but white wine treated at $400 \mathrm{MPa}$ and $500 \mathrm{MPa}$ had a less fruity taste than the control sample.

To explore the relationships between the physicochemical and sensory attributes of HHP-treated wine samples, Pearson's correlation was performed on the sensory and instrumental data to calculate the correlation coefficients (Table 7: $\mathrm{HHP}$ at $500 \mathrm{MPa}$ for $15 \mathrm{~min}$; other data not shown). The physicochemical parameters for the control sample, including tartaric acid $\left(\mathrm{gL}^{-1}\right)$, reducing sugar $\left(\mathrm{gL}^{-1}\right)$, degree of alcohol (\% v/v), total phenols ( $\mathrm{mg} \mathrm{AG} \mathrm{ML}^{-1}$ ), flavonoids ( $\mathrm{mg}$ quercetin $\left.\mathrm{mL}^{-1}\right)$, and DPPH $\left(\mathrm{mM} \mathrm{TE} \mathrm{mL}^{-1}\right)$, are strongly correlated with the three sensory parameters, alcoholic odours, clarity, and fruity taste; $\mathrm{pH}$ was significantly correlated with alcoholic taste, astringency, and odour defects. None of the physicochemical parameters, including soluble solids ( $\left.{ }^{\circ} \mathrm{brix}\right)$, turbidity (NTU), free $\mathrm{SO}_{2}\left(\mathrm{mg} \mathrm{L}^{-1}\right)$, and total $\mathrm{SO}_{2}\left(\mathrm{mg} \mathrm{L}^{-1}\right)$, showed significant correlations with the sensory parameters (attributes).

The physicochemical parameters for white wine treated at $300 \mathrm{MPa}$ for $5 \mathrm{~min}$, including soluble solids ( ${ }^{\circ} \mathrm{brix}$ ), $\mathrm{pH}$, and free $\mathrm{SO}_{2}\left(\mathrm{mg} \mathrm{L}^{-1}\right)$, were strongly correlated with the following five sensory parameters: alcoholic odours, alcoholic taste, astringency, overall quality, and odour defects. With the 
TABLE 7: Correlation coefficients between physicochemical and sensory characteristics of white wine treated at $500 \mathrm{MPa}$.

\begin{tabular}{|c|c|c|c|c|c|c|c|c|c|}
\hline & Clarity & Color & $\begin{array}{l}\text { Defects } \\
\text { (odour) }\end{array}$ & $\begin{array}{c}\text { Alcoholic } \\
\text { (taste) }\end{array}$ & $\begin{array}{l}\text { Fruity } \\
\text { (taste) }\end{array}$ & $\begin{array}{l}\text { Alcoholic } \\
\text { (odour) }\end{array}$ & $\begin{array}{c}\text { Fruity } \\
\text { (odour) }\end{array}$ & $\begin{array}{l}\text { Astringent } \\
\text { (taste) }\end{array}$ & $\begin{array}{l}\text { Overall } \\
\text { quality }\end{array}$ \\
\hline Soluble solids ( ${ }^{\circ}$ Brix $)$ & $0.998^{* *}$ & -0.500 & 0.500 & 0.500 & -0.866 & 0.001 & -0.500 & $-0.998^{* *}$ & $0.998^{* *}$ \\
\hline $\mathrm{pH}$ & $-0.998^{* *}$ & 0.500 & -0.500 & 0.500 & 0.866 & 0.001 & 0.500 & $0.998^{* *}$ & $-0.998^{* *}$ \\
\hline Turbidity (NTU) & -0.866 & 0.001 & 0.001 & -0.866 & $0.998^{* *}$ & 0.500 & 0 & 0.866 & -0.866 \\
\hline Sulphidric acid $\left(\mathrm{g} \mathrm{L}^{-1}\right)$ & $0.998^{* *}$ & -0.500 & 0.500 & 0.001 & -0.866 & 0.001 & -0.500 & $-0.998^{* *}$ & $0.998^{* *}$ \\
\hline Tartaric acid $\left(\mathrm{g} \mathrm{L}^{-1}\right)$ & $0.945^{* *}$ & -0.756 & 0.756 & 0.189 & -0.6547 & 0.327 & -0.756 & $-0.945^{* *}$ & $0.945^{* *}$ \\
\hline $\begin{array}{l}\text { Reducing sugar } \\
\left(\mathrm{g} \mathrm{L}^{-1}\right)\end{array}$ & -0.866 & 0.001 & 0.001 & -0.866 & $0.998^{* *}$ & 0.500 & 0.001 & 0.866 & -0.866 \\
\hline $\begin{array}{l}\text { Alcoholic degree (\% } \\
\mathrm{v} / \mathrm{v})\end{array}$ & 0.866 & 0.001 & 0.001 & 0.866 & $-0.998^{* *}$ & -0.500 & 0.001 & -0.866 & 0.866 \\
\hline $\mathrm{SO}_{2}$ free $(\mathrm{mg} / \mathrm{L})$ & 0.866 & -0.866 & 0.866 & 0.001 & -0.500 & 0.500 & -0.866 & -0.866 & 0.866 \\
\hline $\mathrm{SO}_{2}$ total $(\mathrm{mg} / \mathrm{L})$ & 0.866 & -0.866 & 0.866 & 0.001 & -0.500 & 0.500 & -0.866 & -0.866 & 0.866 \\
\hline $\begin{array}{l}\text { Total phenolic (mg } \\
\text { AG } \mathrm{mL}^{-1} \text { ) }\end{array}$ & $-0.922^{* *}$ & 0.797 & -0.797 & -0.1245 & 0.604 & -0.388 & 0.797 & 0.9216 & -0.9216 \\
\hline $\begin{array}{l}\text { Flavonoid (mg } \\
\text { quercetin } \mathrm{mL}^{-1} \text { ) }\end{array}$ & 0.759 & 0.184 & -0.184 & 0.9434 & -0.983 & -0.651 & 0.184 & -0.759 & 0.759 \\
\hline $\begin{array}{l}\mathrm{DPPH}(\mathrm{mM} \mathrm{TE} \\
\left.\mathrm{mL}^{-1}\right)\end{array}$ & 0.865 & 0.003 & -0.003 & 0.868 & $-0.998^{* *}$ & -0.503 & 0.003 & -0.865 & 0.865 \\
\hline
\end{tabular}

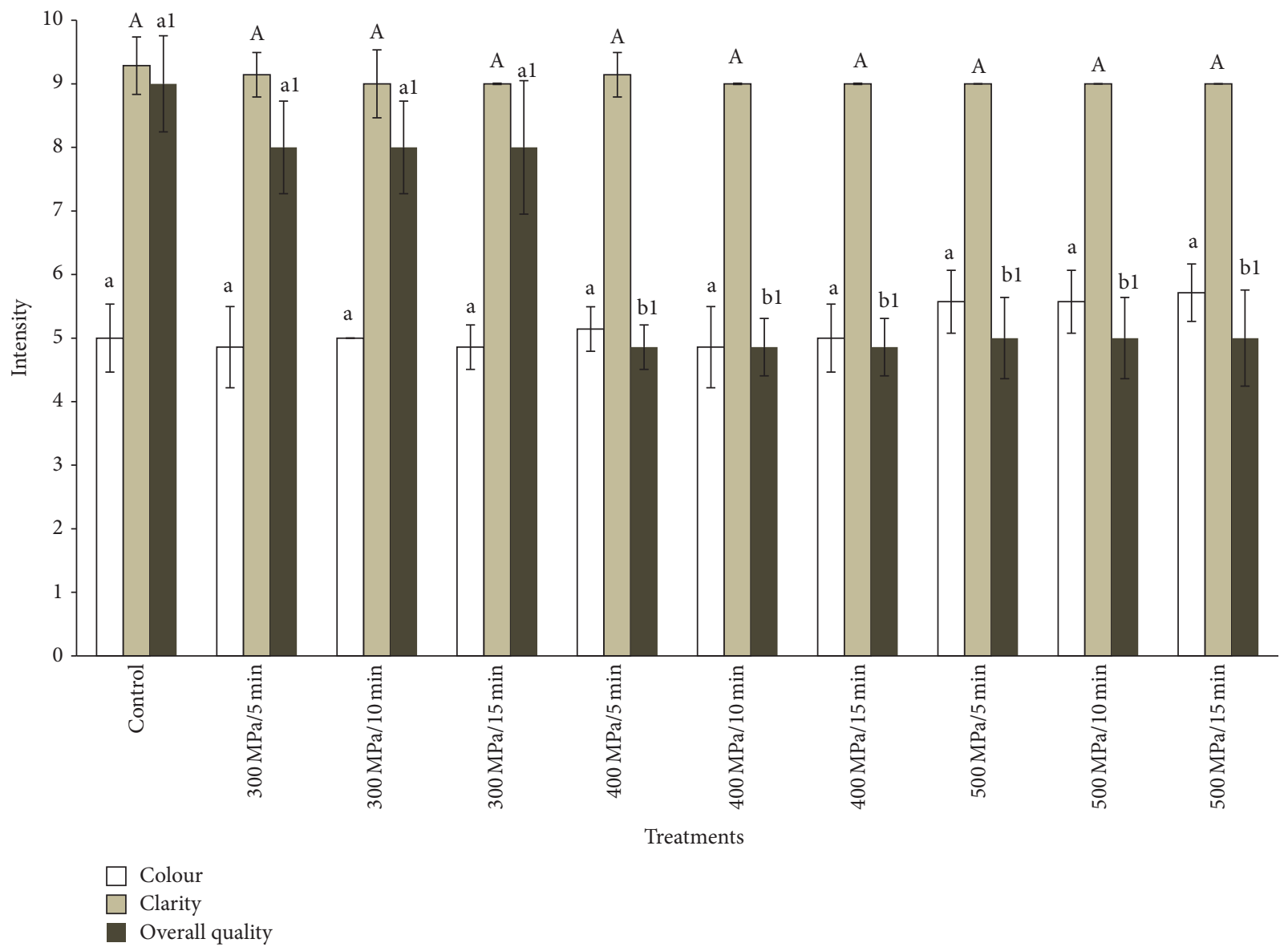

FIGURE 2: Effects of HHP on white wine sensory attributes. Different letters in each bar indicate significant differences between mean values $(p \leq 0.05)$. 

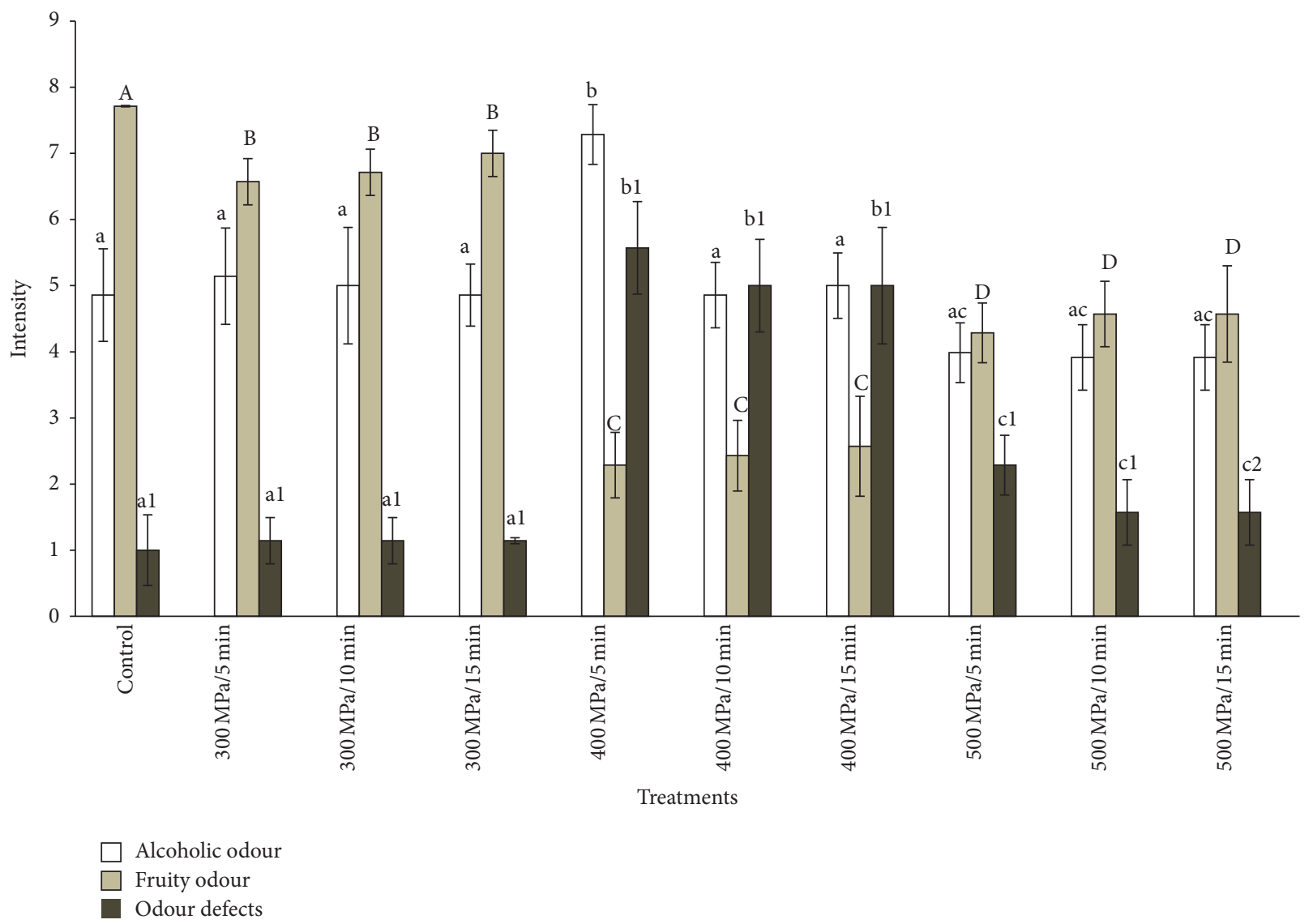

FIGURE 3: Effects of HHP on white wine sensory attributes. Different letters in each bar indicate significant differences between mean values $(p \leq 0.05)$.

exception of turbidity (NTU) and DPPH (mM TE $\left.\mathrm{mL}^{-1}\right)$, they were significantly correlated with fruity odour and fruity taste. None of the physicochemical parameters, including tartaric acid $\left(\mathrm{g} \mathrm{L}^{-1}\right)$, reducing sugar $\left(\mathrm{g} \mathrm{L}^{-1}\right)$, alcohol degree $(\% \mathrm{v} / \mathrm{v})$, total $\mathrm{SO}_{2}\left(\mathrm{mg} \mathrm{L}^{-1}\right)$, total phenols $\left(\mathrm{mg} \mathrm{AG} \mathrm{mL}^{-1}\right)$, and flavonoids (mg quercetin $\mathrm{mL}^{-1}$ ), showed significant correlations with the sensory parameters (attributes).

White wine treated at $300 \mathrm{MPa}$ for $10 \mathrm{~min}$ showed a strong correlation between $\mathrm{pH}$ and the sensory parameters and total $\mathrm{SO}_{2}$ and the sensory parameters. There was also a strong correlation between free $\mathrm{SO}_{2}\left(\mathrm{mg} \mathrm{L}^{-1}\right)$ and four sensory parameters (alcoholic taste, astringency, overall quality, and colour). The other physicochemical parameters were not correlated with the sensory parameters.

For white wine treated at $350 \mathrm{MPa}$ for $15 \mathrm{~min}$, there was only a strong correlation between free $\mathrm{SO}_{2}\left(\mathrm{mg} \mathrm{L}^{-1}\right)$ and all the sensory parameters. None of the physicochemical parameters, including solids ( ${ }^{\circ}$ brix), $\mathrm{pH}$, turbidity (NTU), tartaric acid $\left(\mathrm{g} \mathrm{L}^{-1}\right)$, reducing sugar $\left(\mathrm{g} \mathrm{L}^{-1}\right)$, alcohol degree $(\% \mathrm{v} / \mathrm{v})$, total $\mathrm{SO}_{2}\left(\mathrm{mg} \mathrm{L}^{-1}\right)$, total phenols ( $\mathrm{mg} \mathrm{AG} \mathrm{mL}^{-1}$ ), flavonoids (mg quercetin $\left.\mathrm{mL}^{-1}\right)$, and DPPH $\left(\mathrm{mM} \mathrm{TE} \mathrm{mL}^{-1}\right)$, were significantly correlated with the sensory parameters (attributes).

White wine treated at $400 \mathrm{MPa}$ for $10 \mathrm{~min}$ showed a noticeable correlation only between the physicochemical parameters of total $\mathrm{SO}_{2}\left(\mathrm{mg} \mathrm{L}^{-1}\right)$, free $\mathrm{SO}_{2}\left(\mathrm{mg} \mathrm{L}^{-1}\right)$, and all the sensory parameters, with the exception of alcoholic odour and taste. Furthermore, white wine treated at $400 \mathrm{MPa}$ for $10 \mathrm{~min}$ had a strong correlation among physicochemical parameters, including soluble solids ( ${ }^{\circ}$ brix), reducing sugar $\left(\mathrm{g} \mathrm{L}^{-1}\right)$, total $\mathrm{SO}_{2}\left(\mathrm{mg} \mathrm{L}^{-1}\right)$, flavonoids (mg quercetin $\left.\mathrm{mL}^{-1}\right)$, and the sensory parameters of alcoholic odours and colour. The $\mathrm{pH}$ and free $\mathrm{SO}_{2}\left(\mathrm{mg} \mathrm{L}^{-1}\right)$ had a strong correlation with the sensory parameters of astringency, clarity, and fruity taste. White wine treated at $400 \mathrm{MPa}$ for $15 \mathrm{~min}$ had soluble solids ( ${ }^{\circ}$ brix) that were strongly correlated with alcoholic odour and odour defect. The tartaric acid $\left(\mathrm{g} \mathrm{L}^{-1}\right)$ parameter was strongly correlated with fruity odour while the free $\mathrm{SO}_{2}\left(\mathrm{mg} \mathrm{L}^{-1}\right)$ parameter was also correlated with alcoholic taste, astringency, overall quality, clarity, and fruity taste. Total phenols (mg AG mL ${ }^{-1}$ ) were correlated with alcoholic odour, colour, and odour defect.

Finally, the treatment at $500 \mathrm{MPa}$ for $15 \mathrm{~min}$ had a strong correlation between the physicochemical parameters of soluble solids ( ${ }^{\circ}$ brix), $\mathrm{pH}$, and tartaric acid $\left(\mathrm{g} \mathrm{L}^{-1}\right)$ and the three sensory parameters of astringency, overall quality, and clarity. Turbidity (NTU), reducing sugar $\left(\mathrm{g} \mathrm{L}^{-1}\right)$, and the degree of alcohol (\% v/v) also had a high correlation with fruity taste. None of the other physicochemical parameters exhibited any significant correlations with the sensory parameters (attributes). 

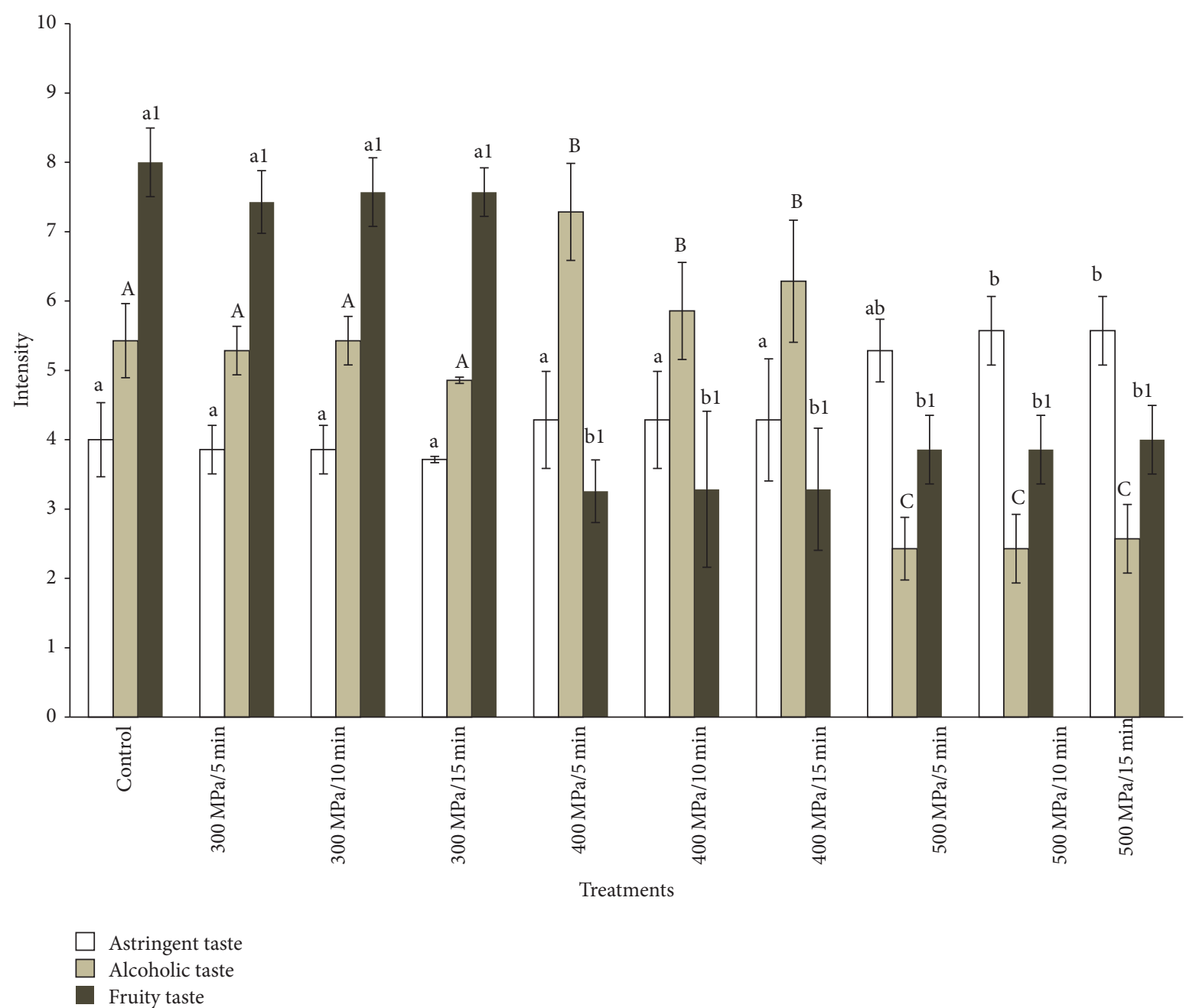

Figure 4: Effects of HHP on white wine sensory attributes. Different letters in each bar indicate significant differences between mean values $(p \leq 0.05)$.

Astringency is regarded as one of the most important organoleptic characteristics of wine. The astringency of HHPtreated wines was positively correlated with free $\mathrm{SO}_{2}$ at $300 \mathrm{MPa}$ and $400 \mathrm{MPa}$ for all the pressurisation times, with the exception at $300 \mathrm{MPa}$ for $5 \mathrm{~min}$ that included soluble solid ( ${ }^{\circ}$ brix) and $\mathrm{pH}$ and $400 \mathrm{MPa}$ for $5 \mathrm{~min}$ that included total $\mathrm{SO}_{2}$. It was positively correlated only with $\mathrm{pH}$ at $500 \mathrm{MPa}$ for $15 \mathrm{~min}$. Some important advantages when using this technology (HHP) in the wine industry are the inactivation of microorganisms and enzymes and quality retention, such as colour and flavour, which could help the wine industry reduces the $\mathrm{SO}_{2}$ levels to produce the same effect.

\section{Conclusions}

Overall, the results of this study indicated that the HHP treatment did not influence the physicochemical parameters of total phenols and flavonoids of white wine. However, the pressurisation at $300 \mathrm{MPa}, 400 \mathrm{MPa}$, and $500 \mathrm{MPa}$ for $15 \mathrm{~min}$ increased free and total $\mathrm{SO}_{2}$, as well as the contents of antioxidant capacity at $300 \mathrm{MPa}$ for all the time and $400 \mathrm{MPa}$ for $5 \mathrm{~min}$ and $10 \mathrm{~min}$ in white wine. Also it is important that the sensory attributes, such as taste, odour, and overall quality, were not affected by HHP processing at $300 \mathrm{MPa}$. The use of this technique has the potential to decrease the amount of $\mathrm{SO}_{2}$ added to raw grapes maintaining the same properties found in untreated wine. This enhances the process because of the problem associated with adding of $\mathrm{SO}_{2}$. The potential of HHP technology is huge for wine industries, and this study has shown that HHP treatment not only decreases the microbial load but also improves the organoleptic properties and makes imperceptible colour changes during the process. However, HHP use for wine conservation is only viable in the final stage of winemaking, replacing the addition of $\mathrm{SO}_{2}$ before bottling. Their use in previous winemaking stages may interfere with the natural fermentation process affecting the fungi, yeast, and the acid lactic bacteria present in the grapes. This study provided valuable insights into the biochemical and sensory composition of commercial white wine and how this might change during HHP processing. 


\section{Additional Points}

Practical Applications. The high hydrostatic pressure is a technology that can contribute to the food industrial development as an alternative to thermal processing. It is an ecofriendly and a time-saving process that improves the stability of bioactive compounds and inhibits the microbiological activity to obtain safe food products by preventing undesirable changes in the sensory, physicochemical, and nutritional properties of foods.

\section{Competing Interests}

The authors declared no conflict of interests with respect to the authorship and/or publication of this article.

\section{Acknowledgments}

The authors wish to acknowledge the financial support for this research from the CONICYT Fondef Project no. D10I1170, CEAZA, Food Engineering Department of the Universidad de La Serena, and the Research Department of the Universidad de La Serena (DIULS).

\section{References}

[1] M. Revi, A. Badeka, S. Kontakos, and M. G. Kontominas, "Effect of packaging material on enological parameters and volatile compounds of dry white wine," Food Chemistry, vol. 152, pp. 331-339, 2014.

[2] J. Torrens, M. Riu-Aumatell, E. López-Tamames, and S. Buxaderas, "Volatile compounds of red and white wines by headspace-solid-phase microextraction using different fibers," Journal of Chromatographic Science, vol. 42, no. 6, pp. 310-316, 2004.

[3] K. M. Considine, A. L. Kelly, G. F. Fitzgerald, C. Hill, and R. D. Sleator, "High-pressure processing-effects on microbial food safety and food quality," FEMS Microbiology Letters, vol. 281, no. 1, pp. 1-9, 2008.

[4] S. Buzrul, "High hydrostatic pressure treatment of beer and wine: a review," Innovative Food Science and Emerging Technologies, vol. 13, pp. 1-12, 2012.

[5] M. Yaldagard, S. A. Mortazavi, and F. Tabatabaie, "The principles of ultra high pressure technology and its application in food processing/preservation: a review of microbiological and quality aspects," African Journal of Biotechnology, vol. 7, no. 16, pp. 2739-2767, 2008.

[6] T. Norton and D.-W. Sun, "Recent advances in the use of high pressure as an effective processing technique in the food industry," Food and Bioprocess Technology, vol. 1, no. 1, pp. 2-34, 2008.

[7] W. Suthanthangjai, P. Kajda, and I. Zabetakis, "The effect of high hydrostatic pressure on the anthocyanins of raspberry (Rubus idaeus)," Food Chemistry, vol. 90, no. 1-2, pp. 193-197, 2005.

[8] F. Zhang, P. Dong, L. Feng et al., "Textural changes of yellow peach in pouches processed by high hydrostatic pressure and thermal processing during storage," Food and Bioprocess Technology, vol. 5, no. 8, pp. 3170-3180, 2012.

[9] Y. Tao, D.-W. Sun, A. Górecki et al., "Effects of high hydrostatic pressure processing on the physicochemical and sensorial properties of a red wine," Innovative Food Science and Emerging Technologies, vol. 16, pp. 409-416, 2012.
[10] M. Corrales, P. Butz, and B. Tauscher, "Anthocyanin condensation reactions under high hydrostatic pressure," Food Chemistry, vol. 110, no. 3, pp. 627-635, 2008.

[11] M. C. Santos, C. Nunes, J. Cappelle et al., "Effect of high pressure treatments on the physicochemical properties of a sulphur dioxide-free red wine," Food Chemistry, vol. 141, no. 3, pp. 25582566, 2013.

[12] X. Chen, L. Li, Y. You, B. Mao, W. Zhao, and J. Zhan, "The effects of ultra-high pressure treatment on the phenolic composition of red wine," South African Journal of Enology \& Viticulture, vol. 33, no. 2, pp. 203-214, 2012.

[13] G. Tabilo-Munizaga, T. A. Gordon, R. Villalobos-Carvajal et al., "Effects of high hydrostatic pressure (HHP) on the protein structure and thermal stability of Sauvignon blanc wine," Food Chemistry, vol. 155, pp. 214-220, 2014.

[14] C. Mok, K.-T. Song, Y.-S. Park, S. Lim, R. Ruan, and P. Chen, "High hydrostatic pressure pasteurization of red wine," Journal of Food Science, vol. 71, no. 8, pp. M265-M269, 2006.

[15] C. Delfini, L. Conterno, G. Carpi et al., "Microbiological stabilisation of grape musts and wines by high hydrostatic pressures," Journal of wine research, vol. 6, no. 2, pp. 143-151, 1995.

[16] A. Lonvaud-Funel, G. Dupont, G. Demazeau, and J. Bignon, "Essais de mutage de vins blancs liquoreux par traitement aux hautes pressions," Journal International des Sciences de la Vigne et du Vin, vol. 28, no. 1, pp. 57-66, 2016.

[17] Commision, E., Commission Regulation(EEC) No 000/90 Determining Community methods for the analysis of wines. Off. Newsp. Eur. Communities 1-192, 1990.

[18] M. L. G.-M. Martin, W. Ji, R. Luo, J. Hutchings, and F. J. Heredia, "Measuring colour appearance of red wines," Food Quality and Preference, vol. 18, no. 6, pp. 862-871, 2007.

[19] B. Berké and V. de Freitas, "A colorimetric study of oenin copigmented by procyanidins," Journal of the Science of Food and Agriculture, vol. 87, no. 2, pp. 260-265, 2007.

[20] M. S. Fernández-Pachón, D. Villaño, A. M. Troncoso, and M. C. García-Parrilla, "Determination of the phenolic composition of sherry and table white wines by liquid chromatography and their relation with antioxidant activity," Analytica Chimica Acta, vol. 563, no. 1-2, pp. 101-108, 2006.

[21] F. Que, L. Mao, X. Fang, and T. Wu, "Comparison of hot airdrying and freeze-drying on the physicochemical properties and antioxidant activities of pumpkin (Cucurbita moschata Duch.) flours," International Journal of Food Science and Technology, vol. 43, no. 7, pp. 1195-1201, 2008.

[22] I. Dini, G. C. Tenore, and A. Dini, "Antioxidant compound contents and antioxidant activity before and after cooking in sweet and bitter Chenopodium quinoa seeds," LWT_Food Science and Technology, vol. 43, no. 3, pp. 447-451, 2010.

[23] ISO 8586-2: 1994. Assessor for Sensory Analysis. Part 2. Guide to the Selection, Training and Monitoring of Experts International Organisation for Standardisation, Geneva, Switzerland, 1994.

[24] R. S. Jackson, "Sensory analysis—methodology—general guidance for establishing a sensory profile," in Wine Science: Principles and Applications, pp. 332-417, Elsevier/Academic Press, San Diego, Calif, USA, 3rd edition, 2008.

[25] ISO, "Sensory analysis-general guidance for the design of test rooms," ISO 8589:1998, International Organization for Standardization, 1998.

[26] M. Dufrechou, C. Poncet-Legrand, F.-X. Sauvage, and A. Vernhet, "Stability of white wine proteins: combined effect of $\mathrm{pH}$, 
ionic strength, and temperature on their aggregation," Journal of Agricultural and Food Chemistry, vol. 60, no. 5, pp. 1308-1319, 2012.

[27] S. Kallithraka, M. I. Salacha, and I. Tzourou, "Changes in phenolic composition and antioxidant activity of white wine during bottle storage: accelerated browning test versus bottle storage," Food Chemistry, vol. 113, no. 2, pp. 500-505, 2009.

[28] H. Vally and P. J. Thompson, "Role of sulfite additives in wine induced asthma: single dose and cumulative dose studies," Thorax, vol. 56, no. 10, pp. 763-769, 2001.

[29] R. S. Jackson, Wine Science: Principles and Applications, Elsevier/Academic Press, San diego, Calif, USA, 3rd edition, 2008.

[30] C. Liu, R. Chen, and Y.-C. Su, "Bactericidal effects of wine on Vibrio parahaemolyticus in oysters," Journal of Food Protection, vol. 69, no. 8, pp. 1823-1828, 2006.

[31] A. W. Burgstahler and M. A. Robinson, "Fluoride in California wines and raisins," Fluoride, vol. 30, no. 3, pp. 142-146, 1997.

[32] M. Costanigro, C. Appleby, and S. D. Menke, "The wine headache: consumer perceptions of sulfites and willingness to pay for non-sulfited wines," Food Quality and Preference, vol. 31, no. 1, pp. 81-89, 2014.

[33] Y. Fu, L.-T. Lim, and P. D. McNicholas, "Changes on enological parameters of white wine packaged in bag-in-box during secondary shelf life," Journal of Food Science, vol. 74, no. 8, pp. C608-C618, 2009.

[34] J. Ahmed and H. S. Ramaswamy, "High pressure processing of fruit and vegetables," Stewart Postharvest Review, vol. 1, pp. 1-10, 2006.

[35] K. N. Prasad, E. Yang, C. Yi, M. Zhao, and Y. Jiang, "Effects of high pressure extraction on the extraction yield, total phenolic content and antioxidant activity of longan fruit pericarp," Innovative Food Science and Emerging Technologies, vol. 10, no. 2, pp. 155-159, 2009.

[36] P. Butz, A. Fernández García, R. Lindauer, S. Dieterich, A. Bognár, and B. Tauscher, "Influence of ultra high pressure processing on fruit and vegetable products," Journal of Food Engineering, vol. 56, no. 2-3, pp. 233-236, 2003.

[37] V. Falguera, M. Forns, and A. Ibarz, "UV-vis irradiation: an alternative to reduce $\mathrm{SO}_{2}$ in white wines?" LWT-Food Science and Technology, vol. 51, no. 1, pp. 59-64, 2013.

[38] M. J. Gómez-Míguez, M. Gómez-Míguez, I. M. Vicario, and F. J. Heredia, "Assessment of colour and aroma in white wines vinifications: effects of grape maturity and soil type," Journal of Food Engineering, vol. 79, no. 3, pp. 758-764, 2007.

[39] M. Clariana, J. Valverde, H. Wijngaard, A. M. Mullen, and B. Marcos, "High pressure processing of swede (Brassica napus): impact on quality properties," Innovative Food Science and Emerging Technologies, vol. 12, no. 2, pp. 85-92, 2011.

[40] N. E. Ferreira-Lima, V. M. Burín, and M. T. Bordignon-Luiz, "Characterization of Goethe white wines: influence of different storage conditions on the wine evolution during bottle aging," European Food Research and Technology, vol. 237, no. 4, pp. 509520, 2013.

[41] M. N. Mitić, M. V. Obradović, Z. B. Grahovac, and A. N. Pavlović, "Antioxidant capacities and phenolic levels of different varieties of Serbian white wines," Molecules, vol. 15, no. 3, pp. 2016-2027, 2010.

[42] I. G. Roussis, I. Lambropoulos, P. Tzimas et al., "Antioxidant activities of some Greek wines and wine phenolic extracts," Journal of Food Composition and Analysis, vol. 21, no. 8, pp. 614621, 2008.
[43] J. Xi, D. Shen, S. Zhao, B. Lu, Y. Li, and R. Zhang, "Characterization of polyphenols from green tea leaves using a high hydrostatic pressure extraction," International Journal of Pharmaceutics, vol. 382, no. 1-2, pp. 139-143, 2009.

[44] R. Noguerol-Pato, R. M. González-Rodríguez, C. GonzálezBarreiro, B. Cancho-Grande, and J. Simal-Gándara, "Influence of tebuconazole residues on the aroma composition of Mencía red wines," Food Chemistry, vol. 124, no. 4, pp. 1525-1532, 2011.

[45] J. Oliva, A. Zalacain, P. Payá, M. R. Salinas, and A. Barba, "Effect of the use of recent commercial fungicides, under good and critical agricultural practices, on the aroma composition of Monastrell red wines," Analytica Chimica Acta, vol. 617, no. 1-2, pp. 107-118, 2008.

[46] Z.-M. Xi, Y.-S. Tao, L. Zhang, and H. Li, "Impact of cover crops in vineyard on the aroma compounds of Vitis vinifera L. cV Cabernet Sauvignon wine," Food Chemistry, vol. 127, no. 2, pp. 516-522, 2011.

[47] D. L. Capone, D. W. Jeffery, and M. A. Sefton, "Vineyard and fermentation studies to elucidate the origin of 1,8-cineole in Australian red wine," Journal of Agricultural and Food Chemistry, vol. 60, no. 9, pp. 2281-2287, 2012.

[48] K. R. Kennison, K. L. Wilkinson, H. G. Williams, J. H. Smith, and M. R. Gibberd, "Smoke-derived taint in wine: effect of postharvest smoke exposure of grapes on the chemical composition and sensory characteristics of wine," Journal of Agricultural and Food Chemistry, vol. 55, no. 26, pp. 10897-10901, 2007.

[49] K. L. Wilkinson, R. Ristic, K. A. Pinchbeck et al., "Comparison of methods for the analysis of smoke related phenols and their conjugates in grapes and wine," Australian Journal of Grape and Wine Research, vol. 17, no. 2, pp. S22-S28, 2011.

[50] A. M. Martínez-Gil, M. Angenieux, A. I. Pardo-García, G. L. Alonso, H. Ojeda, and M. R. Salinas, "Glycosidic aroma precursors of Syrah and Chardonnay grapes after an oak extract application to the grapevines," Food Chemistry, vol. 138, no. 2-3, pp. 956-965, 2013.

[51] A. M. Martínez-Gil, T. Garde-Cerdán, L. Martínez, G. L. Alonso, and M. Rosario Salinas, "Effect of an oak extract applied to 'Verdejo' vineyard on grape composition," Acta Horticulturae, vol. 931, pp. 339-344, 2012.

[52] A. M. Martínez-Gil, T. Garde-Cerdán, A. Zalacain, A. I. PardoGarcía, and M. R. Salinas, "Applications of an oak extract on Petit Verdot grapevines. Influence on grape and wine volatile compounds," Food Chemistry, vol. 132, no. 4, pp. 1836-1845, 2012.

[53] A. M. Martínez-Gil, T. Garde-Cerdán, L. Martínez, G. L. Alonso, and M. R. Salinas, "Effect of oak extract application to Verdejo grapevines on grape and wine aroma," Journal of Agricultural and Food Chemistry, vol. 59, no. 7, pp. 3253-3263, 2011.

[54] S. E. Ebeler, "Analytical chemistry: unlocking the secrets of wine flavor," Food Reviews International, vol. 17, no. 1, pp. 45-64, 2001. 

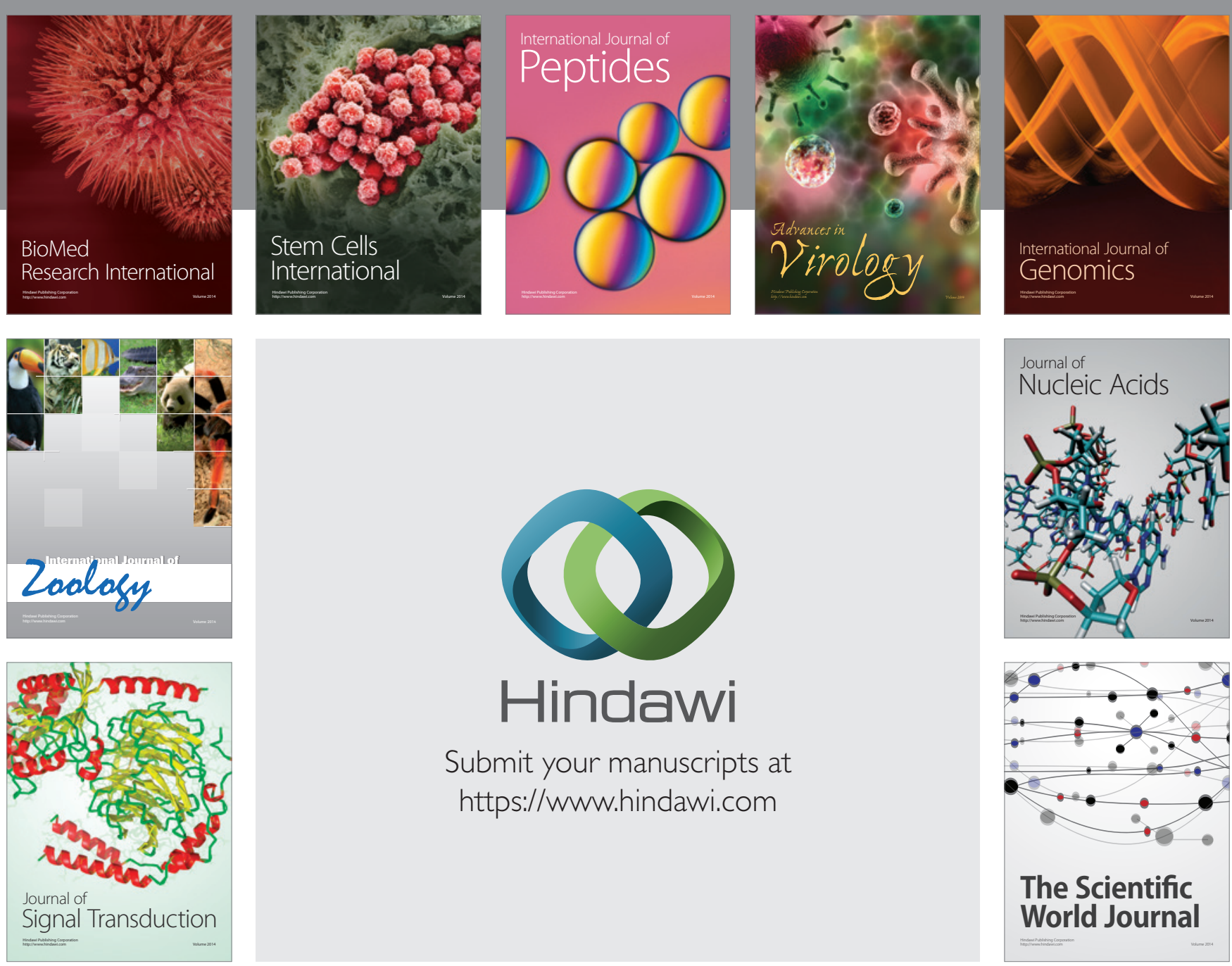

Submit your manuscripts at

https://www.hindawi.com
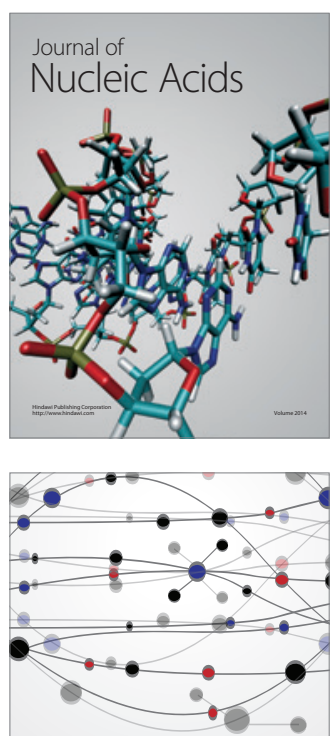

The Scientific World Journal
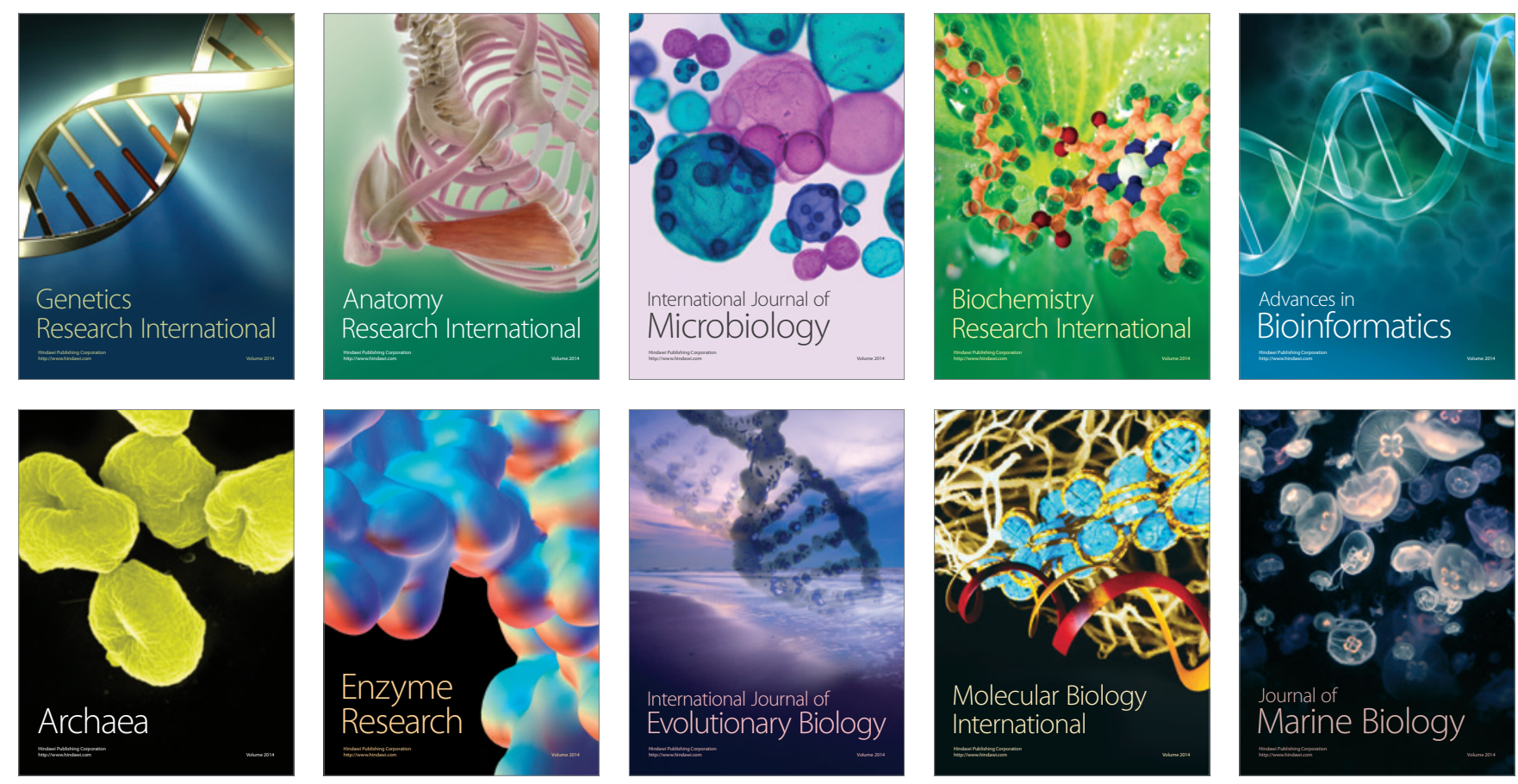